Marzena Grzybowska

DOI $10.15290 / \mathrm{sw} .2016 .16 .02$

Uniwersytet Warszawski

Wydział Lingwistyki Stosowanej

Katedra Studiów Interkulturowych Europy Środkowo-Wschodniej

tel.: +48 22553422

e-mail:m.jaloza@uw.edu.pl

\title{
Z dziejów białoruskiej prawosławnej prasy na emigracji. Czasopismo „Carkoŭny Świetacz” (1951-1988)
}

Słowa kluczowe: prawosławie, autokefalia, emigracja, Białorusini

Po II wojnie światowej jednym z największych skupisk emigracji białoruskiej na Zachodzie były Stany Zjednoczone. Pod względem religijnym przeważną większość emigrantów narodowości białoruskiej stanowili wyznawcy Kościoła prawosławnego. Według źródeł wytworzonych na emigracji ich odsetek wynosił przeszło 80\%. Życie religijne emigrantów już stanowiło przedmiot dociekań badaczy [Касяк, 1956; Мартос, 1966; Вініцкі, 1994; Гарбінскі, 2009; Mironowicz, 2010, 116-134]. Niemniej jednak temat ten wciąż jest słabo zbadany. Białoruska emigracja prawosławna była jednak podzielona wewnętrznie. Emigranci białoruscy wyznania prawosławnego znajdowali się w jurysdykcji dwóch organizacji kościelnych. Jedną grupę tworzyli zwolennicy Białoruskiej Autokefalicznej Cerkwi Prawosławnej. Do drugiej należeli członkowie wspólnot Białoruskiej Cerkwi Prawosławnej w jurysdykcji patriarchatu konstantynopolitańskiego. U podstaw tego podziału leżały względy polityczne. Rozłam kościelny był pokłosiem rozłamu politycznego w białoruskim obozie niepodległościowym na obczyźnie. Parafie autokefalistów skupiały zwolenników Rady Białoruskiej Republiki Ludowej na uchodźstwie z prezydentem Mikołajem Abramczykiem na czele. Utworzenie BACP na emigracji odbyło się w Niemczech w 1948 r. pod auspicjami Rady BRL. Powiązanie BACP z działaczami Rady BRL odtrącało od Bia- 
łoruskiej Autokefalicznej Cerkwi Prawosławnej emigrantów, którzy znaleźli się w opozycji wobec prezydenta Abramczyka. Byli oni skupieni wokół Białoruskiej Rady Centralnej z prezydentem Radosławem Ostrowskim na czele. Zwolennicy BCR wyszli z inicjatywą utworzenia Cerkwi Białoruskiej na emigracji niezależnej od autokefalistów. Działania w tym kierunku podjęto dopiero w roku 1950. Podczas zjazdu prawosławnych Białorusinów w South River 23 listopada 1950 r. zawiązał się Białoruski Prawosławny Komitet Cerkiewny w Ameryce (BPKCA). Założyciele tego komitetu postawili sobie za cel uporządkowanie białoruskiego życia cerkiewnego „na zdrowym i stałym gruncie” [„Царкоўны Сьветач” 1951, nr 1, 4]. Wówczas wybrano również zarząd komitetu, w skład którego weszli: Włodzimierz Brylewski (prezes), Światosław Kowsz, Mikołaj Sieńko, Rościsław Zawistowicz, Wiktor Litarowicz, Teodor Wysocki. Organizatorzy uważali, że uzyskanie niezależności Białoruskiej Cerkwi Prawosławnej jest możliwe jedynie w oparciu o patriarchę ekumenicznego. W związku z powyższym zwrócono się do egzarchy patriarchy konstantynopolitańskiego na Amerykę Północną i Południową arcybiskupa Michała o przyjęcie białoruskiej wspólnoty prawosławnej w swoją jurysdykcję. Egzarcha, który miał siedzibę w Nowym Jorku, uczynił zadość emigrantom białoruskim. Kolejnym krokiem stało się uznanie wspomnianego komitetu przez władze amerykańskie, co umożliwiło organizatorom legalną działalność. Uzyskano m.in. prawo do budowania świątyń i cmentarzy, zakładania szkół, uprawiania działalności wydawniczej, prowadzenia działalności misyjnej [„Царкоўны Сьветач” 1951, nr 1, 4-5]. Egzarcha patriarchy ekumenicznego pieczołowicie otoczył wiernych białoruskich opieką pasterską. Co roku arcybiskup składał życzenia Białorusinom z okazji świąt bożonarodzeniowych i wielkanocnych. Duchowieństwo greckie uczestniczyło w nabożeństwach świątecznych. Przykładowo w marcu 1952 r. w greckiej katedrze metropolitarnej w Nowym Jorku egzarcha patriarchy ekumenicznego arcybiskup Michał celebrował nabożeństwo dziękczynne w intencji święta niepodległości Białorusi [„Царкоўны Сьветач” 1952, nr 2, 10]. Biskupi greccy w asyście księży Białorusinów dokonywali poświęceń nowo otwartych świątyń. Nie ulega wątpliwości, że najliczniejsza parafia białoruska pod wezwaniem św. Eufrozyny Połockiej w jurysdykcji patriarchatu konstantynopolitańskiego powstała w miejscowości South River (stan New Jersey). Proboszczem tej parafii był ks. Mikołaj Łapicki, absolwent Studium Teologii Prawosławnej Uniwersytetu Warszawskiego, znany białoruski działacz religijny i społeczny. Duchowny ten położył bardzo duże zasługi na niwie białoruskiego życia religijnego na emigracji [Garbiński, Turonek 2003, 221-223; zob. również: Лапіцкі 2005]. 5 czerwca 1954 r. arcybiskup Michał podniósł proboszcza parafii w South River ks. Mikołaja Łapickiego do god- 
ności protoprezbitera z prawem noszenia mitry [„Царкоўны Сьветач” 1954, nr 1, 12-13]. Zdając sobie sprawę z ciężkiej sytuacji materialnej emigrantów białoruskich władyka zwolnił parafię w South River z podatku diecezjalnego. Nie powinno więc dziwić to, że śmierć władyki w 1958 r. głęboko poruszyła wiernych - Białorusinów [„Царкоўны Сьветач” 1958, nr 1, 1-5].

Parafia w South River wykazywała dużo energii w rozwoju organizacyjnym, religijnym i kulturalno-oświatowym. Obok aktywności charytatywnej i kulturalno-oświatowej rozwinięto również działalność wydawniczą. Od 1951 r. zaczęto wydawać pismo „Carkoŭny Świetacz”, które ukazywało się nieprzerwanie do $1988 \mathrm{r}$. Wydawcą był wspomniany wcześniej Białoruski Prawosławny Komitet Cerkiewny w Ameryce. W rzeczywistości główny ciężar pracy związanej z wydaniem czasopisma spoczął na barkach ks. Łapickiego. Wydanie czasopisma było możliwe dzięki ofiarności wiernych, którzy wpłacali środki na fundusz wydawniczy. Po wydaniu pierwszego numeru czasopisma redakcja apelowała do czytelników о czynne wsparcie: "Царкоўнь Сьветач" вылдаеича высілкам людзей добрае волі, якія з сваіх скромньх заробкаў складаючь пасільную ахвяру у наш выцавецкі фонд. Гэтая ахвярнасьць $і$ дала нам магчымасчі выпусиіиь у свет першы нумар нашага часапісу. Мы верым у тое, што на гэтую ініцьятывьу адгукнециа наша грамадзкасць $і$ дасць нам магчьлмасьиь прадаўжачь выдавеитва "Царкойнага Сьветача", прьи чьлм у будучыні мы маем замер перайсьчі з дзешавейшага Фатаграфічнага на даражэйшы літаграфічны тыл [„Царкоўны Сьветач” 1951, nr 1,22]. Czasopismo ukazywało się raz lub dwa razy do roku w zależności od możliwości finansowych. Przez cały ten czas nie uporano się z trudnościami natury materialnej. Niemniej nigdy nie przerwano i nie zawieszono wydawania.

Periodyk ten stanowi niezwykle cenne źródło do badań nad historią białoruskiego życia prawosławnego na Zachodzie. Na łamach czasopisma publikowano teksty o treści religijnej, społecznej, historycznej, kulturalnej. Za sprawą periodyku w sposób szczegółowy można odtworzyć dzieje życia prawosławnego emigracji białoruskiej w Ameryce. Dotyczy to nie tylko parafii św. Eufrozyny Połockiej, lecz również innych wspólnot białoruskich, nie tylko prawosławnych. Czasopismo „Carkoŭny Świetacz” można uznać również za świetne źródło dotyczące historii stosunków międzykościelnych na emigracji. Ukazuje ono cały wachlarz kontaktów i współpracy pomiędzy diasporą białoruską a emigrantami greckimi, bułgarskimi, albańskimi, serbskimi. Na łamach czasopisma pisano m.in. o organizacji parafii białoruskich w Kanadzie, Australii, Wielkiej Brytanii. Do redakcji docierały informacje z odległej Kalifornii, Chicago i innych miejsc, gdzie działały or- 
ganizacje i grupy białoruskie. Zamieszczano także utwory literackie. Na łamach czasopisma "Carkoŭny Świetacz” dużo miejsca poświęcano dziejom prawosławia na ziemiach białoruskich. Ukazywały się artykuły okolicznościowe z okazji jubileuszów i świąt religijnych. Oczywiście nie uszła uwadze wydawców czasopisma pięćsetna rocznica cudu pojawienia się Ikony Matki Bożej Żyrowickiej [„Царкоўны Сьветач” 1970, nr 1(19), 5-9]. Tworzono martyrologię męczenników za wiarę i Cerkiew Białoruską, w której poczesne miejsce zajmowała postać metropolity Melchizedeka (Pajewskiego) [C. K., 1957, 10-12; Высочкі 1960, 10-12]. Poczesne miejsce w panteonie bohaterów zasłużonych dla Cerkwi prawosławnej zajmowała również postać księcia Konstantyna Ostrogskiego [Лапіцкi 1958, nr 1, 8-12]. Przeważały publikacje o charakterze popularnonaukowym mające na celu promocję historii. Niemniej jednak zdarzały się również artykuły o wartości naukowej, oparte na solidnej literaturze przedmiotu [zob.: Белямук 1980, nr 29, 18-25]. Zamieszczano także artykuły poświęcone historii i tradycji chrześcijaństwa. Informowano o wydarzeniach zachodzących w życiu Kościoła chrześcijańskiego, jak również o relikwiach chrześcijańskich (np.: sałun turyński, relikwie św. Mikołaja w Bari) [Турынская... 1981, nr 30, 6-7; 900-годзьдзе... 1988, nr 41, 13-24].

Informowano na bieżąco o życiu diaspory białoruskiej. Autorzy ustosunkowywali się zwłaszcza do spraw religijnych emigrantów. Informowano o życiu „konkurencyjnej” Białoruskiej Autokefalicznej Cerkwi Prawosławnej. Pisano m.in. o konflikcie wewnątrz autokefalistów, do którego doszło w latach osiemdziesiątych [Беларуская... 1980, nr 29, 30-31]. Stosunki z wiernymi i duchowieństwem BACP cechowała nieufność i niechęć. Działacze skupieni wokół czasopisma "Carkoŭny Świetacz” uważali BACP za fikcję i etap przejściowy z prawosławia do katolicyzmu. Reaktywację BACP na uchodźstwie określano ,intrygą watykańską". Wychodzono z założenia, że niekanoniczność BACP będzie dyskredytować Białorusinów w oczach innych. Z kolei „autokefaliści” zarzucali „kanonistom” rzekome wyrzeczenie się zasad autokefalii i przejście na łono obcego kościoła. Posądzano ich o tendencje rusofilskie, co jednak nie było zgodne z prawdą. Na łamach prasy wydawanej przez obydwie strony roiło się od wzajemnych zarzutów i oskarżeń. Ks. M. Łapicki na łamach swojego czasopisma potrafił w sposób stanowczy odpierać zarzuty adwersarzy. Problematyka poruszana na łamach czasopisma doskonale oddaje atmosfere panującą w środowisku powojennej emigracji białoruskiej na Zachodzie. Emigracja była podzielona i zwaśniona. Podziały polityczne nierzadko nakładały się na podziały wynikające z ambicji poszczególnych przywódców emigracyjnych. Prowadzone z zawziętością i zaciekłością dyskusje nierzadko przybierały cechy osobistych wycieczek. 
Dużo miejsca poświęcano również własnym sprawom i troskom. Na czoło spraw wysunęła się kwestia powołania diecezji białoruskiej z własnym biskupem w jurysdykcji patriarchy ekumenicznego. Zdawano sobie sprawę, że utworzenie episkopatu białoruskiego na obczyźnie podniosłoby rangę parafii do statusu autonomicznej diecezji (lub cerkwi) w jurysdykcji patriarchatu konstantynopolitańskiego. 10 października 1951 r. arcybiskup Michał przyjął w związku z tą sprawą delegację białoruską. 26 listopada 1957 r. wizytę arcybiskupowi Michałowi złożyli prezydent Białoruskiej Rady Centralnej R. Ostrowski i ks. M. Łapicki. Oficjalnie po raz pierwszy idea mianowania biskupa Białorusina poruszona została podczas zjazdu prawosławnych Białorusinów - duchowieństwa i wiernych w Ameryce, który odbył się 31 sierpnia 1958 r. w South River [Рэзалюцьия... 1958, nr 1, 5]. Z upływem lat problem ten nie przestał być aktualny dla wiernych białoruskich. Świadczy o tym fakt, że 27-28 marca 1970 r. w South Rover odbył się zjazd prawosławnych Białorusinów, na którym wystosowano list do patriarchy Atenagorasa I z prośbą o wyświęcenie biskupa białoruskiego [Яго съвяцейшаму... 1970, nr 1, 31-34]. Z analizy dostępnych źródeł i literatury przedmiotu wynika, że cel ten nie został zrealizowany z powodu braku odpowiednich kandydatów na biskupa [Гардзіенка 2009, 167].

Na łamach „Carkoŭnego Świetacza” zabierano również głos w sprawach statusu Białoruskiej Cerkwi Prawosławnej. W sprawach kościelnych zazwyczaj na łamach swego czasopisma wypowiadał się sam redaktor naczelny. Wbrew zarzutom o wrogi stosunek do autokefalii, które często padały pod adresem ks. M. Łapickiego, duchowny ten był konsekwentnym zwolennikiem niezależności Cerkwi białoruskiej. Nie wyrzekał się autokefalii jako najlepszej formy egzystencji Cerkwi białoruskiej. Uważał jednak, że osiągnięcie tej autokefalii nie może nastąpić za wszelką cenę. Podkreślał, że w tym względzie nie ma drogi „na skróty” z pominięciem kanonów i podstawowych zasad Kościoła powszechnego [Лапіцкі 1967, nr 1, 7-13]. W jednym z artykułów duchowny pisał m.in.: „Праваслаўная Беларуская Царква - гэта Царква нашых прадзедаў, дзядоў $і$ бачькой. Пад яе духойнай апекай падобна як у мінульм так $i$ ияпер мь зможам захавачиа як нацыля, служыць Богу $і$ змагациа за Вольнасьць $і$ Незалежнасьиь Беларусі." [Лапіцкі 1957, nr 1 (8), 9]. Ks. M. Łapicki obstawał przy poglądzie, że ustanowienie Białoruskiej Autokefalicznej Cerkwi Prawosławnej musi nastąpić na zdrowym i kanonicznym gruncie. Utworzenie parafii białoruskich w jurysdykcji patriarchatu konstantynopolitańskiego uważano za pierwszy krok na drodze do autokefalii [Лапіцкі 1953, nr 1(4), 12]. Przejście pod jurysdykcje patriarchy ekumenicznego uważano za powrót na łono Kościoła Matki. Uzasadniano to tym, że na ziemiach białoruskich chrześcijaństwo 
rozpowszechniło się z Bizancjum. Poglądy księdza wymownie oddają jego słowa: „Ад Праваславнай Грэикай Царквы з Бізаниыл ўвесь беларускі народ прыняу Праваслаўную Веру. 3 Бізанцыі, а не з Рыму прыйшло да нас на Беларусь Хрысиіянста, а з ім хрысьиіянская мараль і культура (...) Грэикая Праваслаўная Царква (...) зьяўляеича маткай Беларускай Праваслайнай Царквы. Лучнасць Грэчкай Праваслайнай Царквы-Маткі з Беларускай Праваслаўнай Царквой існуе на прачягаў уссіх стагдзьдзяў $і$ у хвіліну патрэбы Царква-Матка аказвае сваю духовую дапамогу" [Лапіцкі, 1951/1952, nr 2, 7]. Odwoływano się również do dziejów Kościoła prawosławnego Wielkiego Księstwa Litewskiego i Rzeczypospolitej upatrując w nich początki autokefalii białoruskiej. Za datę ukształtowania tej autokefalii uważano rok 1415, kiedy to odbył się sobór biskupów w Nowogródku, na którym proklamowano utworzenie metropolii litewskiej z metropolitą Grzegorzem Cemblakiem na czele [Грэиьия... 1951, nr 1, 7-9].

Napięte stosunki były również z duchowieństwem rosyjskim. O ile nie odnotowano krytycznych artykułów pod adresem duchowieństwa Rosyjskiego Kościoła Prawosławnego za Granicą, o tyle wypowiadano się krytycznie na temat polityki patriarchatu moskiewskiego wobec Białorusi. Zdecydowanie odrzucano rosyjski charakter prawosławia na ziemiach Białorusi. Odmawiano również prawa hierarchom rosyjskim do zwierzchnictwa nad Kościołem prawosławnym na Białorusi. W tych sprawach autorzy „Carkoŭnego Świetacza” polemizowali z przedstawicielami rosyjskiego prawosławia. Proklamowanie z błogosławieństwem patriarchatu moskiewskiego w 1970 r. nowego kościoła autokefalicznego Amerykańskiego Kościoła Prawosławnego spotkało się z dezaprobatą i krytyką Białorusinów [Лaniцкі 1970, nr 1(19), 10-14].

Na łamach czasopisma poruszano również kwestię relacji z innymi kościołami chrześcijańskimi, a przede wszystkim z Kościołem katolickim. Stosunki z przedstawicielami innych wyznań religijnych, w tym z katolikami, na ogół były poprawne. Świadczy o tym współpraca ks. M. Łapickiego z przedstawicielami białoruskiego duchowieństwa rzymskokatolickiego na obczyźnie. Niósł on bratnią pomoc rodakom wyznania katolickiego, którzy nie posiadali własnej świątyni. W związku z powyższym pomagał ks. Franciszkowi Czerniawskiemu w organizacji nabożeństw dla Białorusinów - katolików. Za jego zgodą w drukarni w South River wydawano periodyk katolicki „Siaubit”. Duchowny wypowiadał się z szacunkiem i życzliwością na temat rodaków wyznania rzymskokatolickiego. Wyznawał zasadę, że jako że nie należy do Kościoła katolickiego, nie powinien mieszać się w sprawy wewnętrzne katolików. Oczekiwał również tego samego od strony przeciwnej [3 $\partial a$ - 
кладу... 1960, nr 1, 14]. Utrzymywano również przyjazne stosunki z Ukraińskim Kościołem Greckokatolickim. Inaczej sprawy się miały jeśli chodzi o stosunki z białoruskim duchowieństwem katolickim obrządku wschodniego. Wzajemne relacje cechowała niechęć, a nawet wrogość względem siebie. Świadczy o tym bogata polemika pomiędzy obydwiema stronami na łamach swojej prasy. Przeradzała się ona niekiedy w wycieczki osobiste i oskarżenia [Загонак 1958, nr 1, 13-16]. Sprawę tę należy rozpatrywać w szerszym kontekście. Należy pamiętać, że stosunki wyznaniowe na ziemiach wschodnich II RP, skąd pochodziła większość emigrantów białoruskich, były bardzo złożone i nie były wolne od uprzedzeń i konfliktów. Wyniesione z kraju doświadczenia towarzyszyły wiernym również na emigracji. Po II wojnie światowej na Zachodzie znalazła się grupa księży katolickich obrządku bizantyjsko-słowiańskiego, którzy prężnie rozwinęli działalność misyjną wśród emigrantów. Powstały ośrodki misyjne w Londynie i Paryżu. Tymczasem warto zaznaczyć, że wśród emigrantów - Białorusinów, jak również wśród ich rodaków w kraju, unici stanowili znikomy odsetek. Działalność misyjna postrzegana była przez ks. M. Łapickiego i jego zwolenników jako wtrącanie się w sprawy wewnętrzne innego kościoła oraz działania mające na celu rozbicie spójności emigracji białoruskiej, która w przeważającej większości składała się z prawosławnych [Гардзіенка 2010, 381] ${ }^{1}$. Niewątpliwie dolał oliwy do ognia wywiad dla prasy brytyjskiej udzielony przez ks. Czesława Sipowicza z Białoruskiej Misji Katolickiej (obrządku wschodniego) w Londynie, w którym duchowny oświadczył, że przybył do Anglii w celu nawracania emigrantów na katolicyzm. Wydarzenie to wywołało wielką burzę krytycznych komentarzy w środowisku emigrantów białoruskich [Гардзіенка 2010, 381].

Dodatkowo atmosferę nieufności podsycał fakt, że księża katoliccy byli związani z Radą BRL i jej prezydentem M. Abramczykiem, podczas gdy wydawcy i czytelnicy „Carkoŭnego Świetacza” należeli do obozu popierającego Białoruską Radę Centralną. Podziały polityczne nakładały się na różnice w postrzeganiu pewnych wydarzeń historycznych. W odmienny sposób interpretowano na przykład rolę unii brzeskiej 1596 r. w dziejach narodu białoruskiego. Działacze imigracyjni sympatyzujący z Radą BRL byli skłonni

\footnotetext{
1 Natalia Hardzijenka słusznie zaznacza: „Idea unii często była odbierana przez Biatorusinów bardziej negatywnie niż katolicyzm, ponieważ widziano w niej niebezpieczeństwo rozszerzenia wladzy Watykanu na środowiska prawostawnych. Jest zrozumiate, że działalność misyjna księży greckokatolickich wśród imigrantów białoruskich, których większość stanowili prawosławni, nie mogła nie być niedostrzė̇ona przez inne osoby duchowne".
} 
gloryfikować to wydarzenie upatrując w nim sposób na przezwyciężenie podziałów wyznaniowych wśród Białorusinów. W otoczeniu prezydenta BRL na uchodźstwie nie brakowało apologetów unii, którzy uważali, że ideę tę należy wskrzesić wśród emigrantów. Pomysł ten nie obcy był m.in. prezydentowi M. Abramczykowi, który wykazywał pewne zainteresowanie rozwojem akcji neounitów [Jałoza 2011, 34-36]. Przeciwni temu byli emigranci skupieni wokół BRC. Ksiądz M. Łapicki dał się poznać jako zdecydowany i konsekwentny przeciwnik unii. Duchowny bardzo krytycznie oceniał rolę unii brzeskiej w historii Białorusinów podkreślając jej negatywne cechy. Uważał unię kościelną za źródło poważnych problemów dla narodu białoruskiego i utożsamiał ją z działalnością czynników wrogich Białorusinom. Uważał, że jest ona szkodliwa zarówno dla białoruskich interesów religijnych, jak i narodowych. Przestrzegał również przed negatywnymi skutkami działalności duchowieństwa neounickiego mogącymi prowadzić do kolejnych rozłamów i podziałów wśród emigrantów. Należy zaznaczyć, że tej problematyce poświęcano dość dużo miejsca na łamach "Carkoŭnego Świetacza". Publikowano artykuły zarówno historyczne, jak i dotyczące wydarzeń bieżących. W jednym z numerów „Carkoŭnego Świetacza” ukazała się odezwa duchowieństwa i wiernych Białoruskiej Cerkwi Prawosławnej na obczyźnie w jurysdykcji patriarchatu konstantynopolitańskiego do emigrantów białoruskich różnych wyznań, w której wzywano rodaków do przeciwstawienia się próbom rozniecania wewnętrznych konfliktów religijnych wewnątrz środowiska emigracyjnego. Apelowano również o solidarność emigrantów białoruskich różnych wyznań i trzymanie się zasad poszanowania tolerancji religijnej. Powodem do wydania odezwy stało się wyświęcenie na biskupa w sierpniu 1960 r. wspomnianego wcześniej ks. Cz. Sipowicza. Podkreślano, że istnieje potrzeba organizacji duszpasterskiej dla Białorusinów wyznania rzymskokatolickiego, którzy pozbawieni byli własnych parafii na emigracji. Wyświęcenie biskupa dla bardzo nielicznej grupy emigrantów białoruskich katolików obrządku wschodniego traktowano jako przygotowanie do krucjaty misyjnej Watykanu [Беларуская... 1960, nr 1, 1-3; zob. również: Вокс 1960, nr 1, 4-9].

Na łamach "Carkoŭnego Świetacza” zajmowano także stanowiska w sprawach zachodzących w życiu politycznym na świecie. Dawała się odczuć atmosfera zimnowojenna panująca w ówczesnym społeczeństwie. Tak na przykład w $1955 \mathrm{r}$. zamieszczono obszerny artykuł w związku ze zwróceniem się patriarchy moskiewskiego Aleksego I i trzech biskupów Rosyjskiej Cerkwi Prawosławnej do wspólnoty międzynarodowej w sprawie bezpieczeństwa. Apel hierarchów rosyjskich określano jako kolejna kpina reżimu komunistycznego z Kościoła [ K.S., 1955, nr 1 (6), 2-5.]. Pisano również o naj- 
ważniejszych wydarzeniach zachodzących w życiu Kościoła prawosławnego na świecie. W jednym z numerów „Carkoŭnego Świetacza” solidaryzowano się z przywódca Greków cypryjskich arcybiskupem Makariosem I, który 25 listopada $1958 \mathrm{r}$. wystąpił na forum ONZ w obronie rodaków zamieszkujących wyspę [M. A. 1958, nr 1 (8), 12]. Z dumą pisano również o ustanowieniu regulaminu dla kapelanów wyznania prawosławnego w siłach zbrojnych Stanów Zjednoczonych [Праваслаўная... 1980, nr 29, 26]. Wydawców i autorów „Carkoŭnego Świetacza” łączyły braterskie i przyjazne stosunki z duchowieństwem i wiernymi Ukraińskiej Cerkwi Prawosławnej w Ameryce. Tak na przykład 20 czerwca 1956 r. z okazji święta Żyrowickiej Ikony Matki Bożej arcybiskup Paladiusz przekazał proboszczowi parafii w South River ks. M. Łapickiemu cząstkę kamienia, na którym objawił się święty obraz [Сьвятая... 1956, nr 1 (7), 1-2]. Nie tracono z pola widzenia wydarzeń w kraju. Pisano m.in. o powrocie do Wilna w 1947 r. relikwii Świętych Męczenników Wileńskich [Беларуская... 1957, nr 1 (8), 24]. Zasługuje na uwagę również artykuł ks. M. Łapickiego na temat monasteru w Supraślu. Autor zwrócił uwagę na powrót „Kodeksu z Supraśla” do Polski w 1968 r. [Лапіцкі 1968, nr 29, 4-9]. Nie uszło również uwadze autorów „Carkoŭnego Świetacza" wizyta patriarchy ekumenicznego Dimitriosa I do Polski i Watykanu w listopadzie 1987 r. [Усяленскі... 1988, nr 41, 18-19].

Po śmierci ks. Łapickiego (1976 r.) dzieło wydania periodyku kontynuował ks. Światosław Kowsz, następny proboszcz parafii św. Eufrozyny Połockiej w South River. Duchowny ten w 1977 r. został administratorem wszystkich parafii białoruskich USA i Kanady w jurysdykcji patriarchatu konstantynopolitańskiego. Dzięki jego staraniom czasopismo ukazywało się jeszcze przez kolejnych kilka lat. Po objęciu stanowiska redaktora naczelnego nie uległ zmianie charakter czasopisma. W dalszym ciągu omawiano sprawy historyczne, religijne i społeczno-polityczne. Wówczas białoruskie prawosławie na emigracji stanęło w obliczu nowych problemów i wyzwań. Jednym z nich był brak duchowieństwa i własnego biskupa. Ksiądz Ś. Kowsz zaznaczał jednak, że problemem tym nękani byli nie tylko wierni Cerkwi Białoruskiej, lecz również emigranci innych narodowości i wyznań religijnych [Сабор... 1985, nr 39, 7].

W roku 1988 r. ujrzał światło dzienne ostatni numer „Carkoŭnego Świetacza”. Tym samym dobiegł końca kolejny - bardzo ważny - etap w dziejach białoruskiego prawosławia na emigracji. Czasopismo „Carkoŭny Świetacz" należy do jednych z najdłużej ukazujących się periodyków religijnych diaspory białoruskiej w XX wieku. Jak już wspominano, stanowi on niezwykle cenne źródło dotyczące historii emigracji białoruskiej po II wojnie światowej. Odegrał on niebagatelną rolę w życiu emigrantów-Białorusinów 
wyznania prawosławnego. W białoruskiej społeczności emigracyjnej religia prawosławna stała się jednym z głównych czynników zachowania tożsamości narodowej. Stopień identyfikacji diaspory z prawosławiem był bardzo wysoki. Nie przypadkowo organizacje religijne wykazywały się nieporównanie większą żywotnością niż organizacje polityczne czy jakiekolwiek inne. Na zakończenie warto przytoczyć słowa redakcji „Carkoŭnego Świetacza” napisane w piątą rocznicę istnienia parafii w South River: „На самай справе, чьлм сталася Беларуская Праваслаўная Царква у Саут-Рьъэры для беларускага эмігранта на першай $і$ яшчэ ияперашняй стадыі яго прабыьвання у Новым Свече? Адказваючь каротка - усім: супольныл месиам малітваў, начьянальнымм яднаньнем, кавалачкам старой Бачькаўшчыны" [C.M. 1956, nr 1 (7), 9]. Myślę, że te słowa z pewnością można odnieść do czasopisma „Carkoŭny Świetacz”, ponieważ w owych warunkach zapotrzebowanie na własne słowo drukowane poświęcone problematyce religijnej też było ogromne.

\section{Literatura}

Garbiński J., Turonek J., 2003, Białoruski ruch chrześcijański XX wieku. Stownik biograficzno-bibliograficzny, Warszawa, s. 221-223.

Jałoza M., 2011, Życie religijne uchodźców białoruskich wyznania katolickiego w Niemczech Zachodnich w latach 1945-1951, ,Studia Interkulturowe Europy Środkowo-Wschodniej", t. 6, s. 34-36.

Mironowicz A., 2010, Życie religijne prawostawnej emigracji białoruskiej po II wojnie światowej, „Białoruskie Zeszyty Historyczne” nr 33, s. 116-134.

Белямук М., 1980, Царкоўная архітэктура Панёманшчыныл, „Царкоўны Сьветач", nr 29, s. 18-25.

Вініцкі А., 1994, Матэрыялы да гісторыі беларускай әміграчыі ў Нямеччыне y 1939-1951 гадоx, Mińsk.

Вокс, „Сьиеражьиеся ілжэпрарокаў, каторыя прыходзячь да вас у авечай скуpы, а ў сярэдзіне ёсьщь ваўкамі хіжымі”, „Царкоўны Сьветач” 1960, nr 1, s. $4-9$.

Высочкі Ф., 1960, Жьиьиё Прэпадобнамучаніка Афнасія Берасьщейскаго, „Царкоўны Сьветач”, nr 1, s. 10-12.

Гарбінскі Ю., 2009, Беларускі рэлігійны друк на Захадзе, 1945-2005, Nowy Jork-Warszawa.

Гардзіенка А., 2009, Беларускі кангрэсавы камітэт Амэрыкі (БККА), Smоleńsk,.

Гардзіенка Н., 2010, Беларусы ў Вялікабрытаніi, Mińsk. 
Касяк I., 1956, 3 гісторыі Праваслаўнай Царквы беларускага народу, Nowy Jork.

Коўш А. С., 1970, 500-годзьдзе зьяўленьня Цудадзейнае Іконь Жыровічкае Божкае Маці, „Царкоўны Сьветач”, nr 1(19), s. 5-9.

К.С., 1957, Высокапрэсьвяччэньнейшы Мелхісэдэк, метрапаліт менскі $і$ беларускі, „Царкоўны Сьветач”, nr 1 (8), s. 10-12.

К.С., 1955, Чарговы зьдзек бальшавікоў над Праваслаўнаю Царквою, „Царкойны Сьветач", nr 1 (6), s. 2-5.

Лапіцкі М., 2005, У служэньні Богу й Беларусі, Nowy Jork - Warszawa.

Лапіцкі М., 1958, 350-гадовы юбілей Кн. Канстантына Канстантынавіча Астроскага, „Царкойны Сьветач”, nr 1, s. 8-12.

Лапіцкі М., 1970, Амэрыканска-Маскоўская „Аўтакефалія”, „Царкоўны Сьветач", nr 1, s. 10-14.

Лапіцкі М., 1957, Беларуская Ауттакефальная Праваслаўная Царква і яе гістарычныля даты двачиатага стагодзьдзя, „Царкойны Сьветач”, nr 1 (8), s. 9.

Лапіцкі, М., 1968, Беларускі праваслаўны манастыр у Супрасълі і яго „Супрасльская рукапісь”, „Царкоўны Сьветач”, nr 29, s. 4-9.

Лапіцкі М., 1967, Двачцачіплиігодзьдзе Беларускага Аўтакефальнага Праваслаўнага Сабору. Менск - 1942, „Царкоўны Сьветач”, nr 1, s. 7-13.

Лапіцкі М., 1953, У імя праўды,, „Царкойны Сьветач”, nr 1 (4), s. 12.

Лапіцкі М., 1951/1952, Беларуская Аўтакефальная Праваслаўная Царква, „Царкоўны Сьветач”, nr 2, s. 7.

М.А., 1958, Кіпрская праваслаўная иарква. Прыклад любові да сваёй чарквы $i$ нацыі, „Царкоўны Сьветач”, nr 1 (8), s. 12.

Мартос А., 1966, Беларусь в исторической, государственной и черковной жизни, Buenos Aires.

Загонак К., 1958, Ні Рыл, ні Масква, а незалежны Менск, „Царкоўны Сьветач", nr 1, s. 13-16.

C. М., 1956, Адзначаючь пяиігодзьдзе, „Царкоўны Сьветач”, $\operatorname{nr} 1$ (7), s. 9.

Беларуская Аўтакефальная Праваслаўная Царква інзной на судовай дарозе, „Царкоўны Сьветач” 1980, nr 29, s. 30-31.

Беларуская праваслаўная иарква ў юрысдыцкаі канстантынопальскай патpылярхіi. Адозва, „Царкоўны Сьветач” 1960, nr 1, s. 1-3.

Беларуская хроніка, „Царкоўны Сьветач” 1957, nr 1 (8), s. 24.

Беларускі Праваслаўны Царкойны Камітэт у Амэрыцыь, „Царкоўны Сьветач” 1951, nr 1, s. 4-5.

Грэчьия - крыніча веры нашых продкаў, „Царкойны Сьветач” 1951, nr 1, s. 7-9. Да нашых чытачоў, „Царкоўны Сьветач” 1951, nr 1, s. 22.

Добры пастьр, „Царкоўны Сьветач” 1958, nr 1, s. 1-5.

Дзень Сьв. Езфрасіньні Полачкае ў Сайт Рьъвэр, „Царкоўны Сьветач” 1954, nr 1 , s. $12-13$. 
3 дакладу а. протапрэсьвічера Мікалая Лапічкага, „Сучаснае становішча Беларускай Праваслаўнай Царквы ў вольным сьвече і патрэбныля мерапрыемствы для уัзьняиьия иаркойнага жыцьия", прачытанага на Зьезьдзе беларусаў ЗША і Канады ў Торонто (Канада) дня 4 верасьня 1960 г., „Царкоўны Сьветач” 1960, nr 1, s. 14.

Праваслаўная иарква ўключана ў рэгулямін амэрыканскае арміi, „Царкойны Сьветач" 1980, nr 29, s. 26.

Рэзалюиыя зьезду праваслаўных беларусай: духавентсва і вернікаў з Амэрыкі і Канады з дня 31 жніўня 1958 году у Саўт Рывэры, Нью Джэрсі, СШПА, „Царкоўны Сьветач” 1958, nr 1, s. 5.

Сабор беларускае праваслаўнае епархіі у Паўночнай Амэрыцы 18 траўня 1985 г., „Царкоўны Сьветач” 1985, nr 39, s. 7.

Сввятая $i$ дарагая беларускаму сэриу рэліквія, „Царкойны Сьветач” 1956 , nr 1 (7), s. $1-2$.

Турынская плашчаніча, „Царкоўны Сьветач” 1981, nr 30, s. 6-7

Усяленскі Патрыярх на Беларусі, „Царкойны Сьветач” 1988, nr 41, s. 18-19.

Яго съвячейшаму патрыярху Афінагору I, „Царкоўны Сьветач” 1970, nr 1, s. $31-34$.

900-годзьдзе перанясеньня мошчаў сьв. Мікалая, „Царкоўны Сьветач” 1988, nr 41, s. $13-24$.

\section{FROM THE HISTORY OF BELARUSIAN RELIGIOUS PRESS IN EXILE. THE JOURNAL 'CARKOŬNY SVETAČ' (1951-1988)}

\section{S U M M A R Y}

After World War II the United States was one of the largest centres of Belarusian emigrants in the West. Belarusian Orthodox emigration, which composed the majority among emigrants of Belarusian nationality (80\%) was divided internally. Belarusian emigrants of the Orthodox faith were within the jurisdiction of two church organizations: the Belarusian Autocephalous Orthodox Church and the Belarusian Orthodox Church under the jurisdiction of the Patriarchate of Constantinople. The largest Belarusian parish in the jurisdiction of the Patriarchate of Constantinople was the parish of St Eufrozyna Polocka in South River (New Jersey), where Nicholas Lapicki was the parish priest. There were conducted organizational, religious, cultural and educational activities, including publishing one. In 1951-1988 the journal 'Carkoŭny Svetač' was issued, at first by pr. Nicholas Lapicki and since 1976 by pr. Sviataslav Kovš, the next parish priest of St Eufrozyna Polocka in South River. It belonged to one of the longest published religious periodicals of the Belarusian diaspora in the 20th century. In the journal the texts with religious, social, historical and cultural content were published. Thanks to the 'Carkoŭny Svetač' it is possible to reconstruct in detail the history of the Orthodox life of Belarusian emigrants in America. 